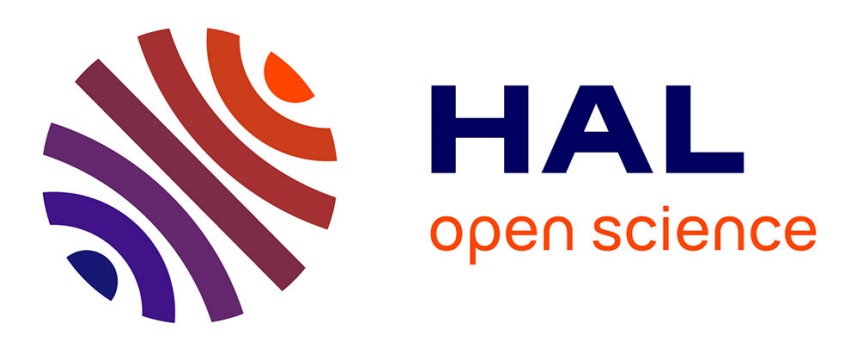

\title{
Aiding multi-level decision-making processes for climate change mitigation and adaptation
}

\author{
K.A. Daniell, M.A.M. Costa, N. Ferrand, A.B. Kingsborough, P. Coad, I.S.
} Ribarova

\section{- To cite this version:}

K.A. Daniell, M.A.M. Costa, N. Ferrand, A.B. Kingsborough, P. Coad, et al.. Aiding multi-level decision-making processes for climate change mitigation and adaptation. Regional Environmental Change, 2010, 11 (2), p. 243 - p. 258. 10.1007/s10113-010-0162-0 . hal-00861177

\section{HAL Id: hal-00861177 https://hal.science/hal-00861177}

Submitted on 12 Sep 2013

HAL is a multi-disciplinary open access archive for the deposit and dissemination of scientific research documents, whether they are published or not. The documents may come from teaching and research institutions in France or abroad, or from public or private research centers.
L'archive ouverte pluridisciplinaire HAL, est destinée au dépôt et à la diffusion de documents scientifiques de niveau recherche, publiés ou non, émanant des établissements d'enseignement et de recherche français ou étrangers, des laboratoires publics ou privés. 


\title{
Aiding multi-level decision-making processes for climate change mitigation and adaptation
}

\author{
Katherine A. Daniell ${ }^{1}$, María A. Máñez Costa ${ }^{2,6}$, Nils Ferrand ${ }^{2}$, Ashley B. Kingsborough ${ }^{3}$, \\ Peter Coad $^{4}$, Irina S. Ribarova ${ }^{5}$
}

${ }^{1}$ Centre for Policy Innovation, The Australian National University, Canberra ACT 0200, Australia katherine.daniell@anu.edu.au, T: +61 26215 2214, F: +61261259767

${ }^{2}$ UMR G-EAU, Cemagref, 361 rue JF Breton, BP 5095, 34196 Montpellier Cedex 5, France

${ }^{3}$ Environmental Change Institute, University of Oxford, South Parks Road, Oxford, OX1 3QY University, Oxford, United Kingdom

${ }^{4}$ Hornsby Shire Council, PO BOX 37 Hornsby NSW 1630, Australia

${ }^{5}$ Faculty of Hydrotechnics, University of Architecture, Civil Engineering and Geodezy, $1 \mathrm{Hr}$. Smirnenski blvd, 1046 Sofia, Bulgaria

${ }^{6}$ Climate change and spatial development. HafenCity Universität Hamburg. Winterhuder Weg 29-31

D- 22085 Hamburg Germany

\section{Paper accepted for the journal "Regional Environmental Change" 15/08/2010}

\begin{abstract}
Progress towards climate change aware regional sustainable development is affected by actions at multiple spatial scales and governance levels, and equally impacts actions at these scales. Many authors and policy practitioners consider therefore that decisions over policy, mitigation strategies and capacity for adaptation to climate change require construction and coordination over multiple levels of governance to arrive at acceptable local, regional and global management strategies. However, how such processes of coordination and decision-aiding can occur and be maintained and improved over time is a major challenge in need of investigation. We take on this challenge by proposing research-supported methods of aiding multi-level decision-making processes in this context. Four example regionally-focussed multi-level case studies from diverse socio-political contexts are outlined - estuarine management in Australia's Lower Hawkesbury, flood and drought management in Bulgaria's Upper Iskar Basin, climate policy integration in Spain's Comunidad Valenciana, and food security in Bangladesh's Faridpur District from which insights are drawn. Our discussion focuses on exploring these insights including: (1) the possible advantages of informal research-supported processes, and specifically those that provide individual arenas of participation for different levels of stakeholders; (2) the complexity of organisation processes required for aiding multi-level decision-making processes; and (3) to what extent progress towards integrated regional policies for climate change aware sustainable development can be achieved through research-supported processes. We finish with a speculative section that provides ideas and directions for future research.
\end{abstract}

\section{Key words}

Multi-level, climate change, participatory process, decision-making, water management, food security 
Author-produced version of the article published in Regional Environmental Change, 2010, 11(2), 243-258.

The original publication is available at http://link.springer.com

DOI : $10.1007 / \mathrm{s} 10113-010-0162-0$

\section{INTRODUCTION}

Climate change is seen as a major issue for the sustainability of the world's socio-ecological systems (Dovers 2005). Driving the sustainable development of regions throughout the world is therefore thought to require climate change aware processes for policy development, decision-making and implementation challenges. In this context, mainstreaming climate change issues into existing policy or "Climate Policy Integration" is touted to be a necessity (Ahmad 2009; Mickwitz et al. 2007; Dovers and Hezri 2010). Yet it remains to be seen how effectively this ideal can be translated into governance practice and what barriers are hindering progress towards climate change aware regional sustainable development. One of the key issues surrounding climate policy integration is that the integration or coordination should ideally take place across all sectors and between levels of governance systems, as the world's climate is affected by actions at multiple spatial scales and governance levels, and equally impacts the actions at these scales. Proponents of such an integrative approach consider this as vital for a number of inter-linked reasons. Firstly, it can be seen that mismatches between highlevel policy-making processes and coordination of local actions for climate change mitigation and adaptation are still common. This is considered to be due to the social uncertainty surrounding local reactions to policy decisions; and local stakeholders' interests and impacts on policy creation, as conceptualized in Figure 1.

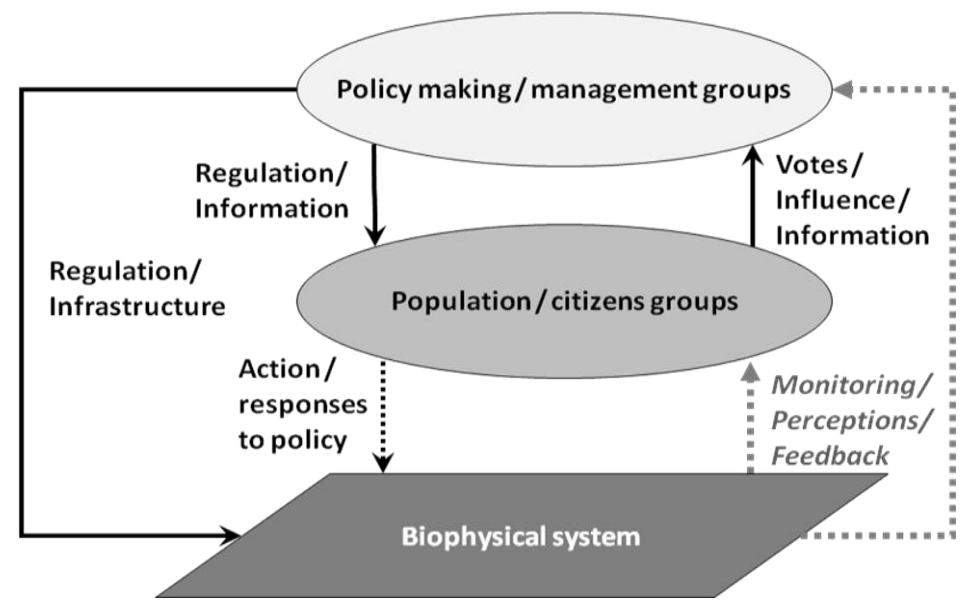

Figure 1 Interactions in a multi-level governance system. Potential mismatches commonly translate into undesired or incompatible actions at local levels compared to policy decisions. This "potential" is highlighted as a dotted black line. Mismatches may also be perceived based on certain undesired observed states and processes of the biophysical system that do not match policy aims and population values. Perceptions of environmental responses to climate change mitigation and adaptation measures, taken at both population and policy levels, are represented by the grey dashed lines.

Considering this situation, enhancing the sustainability and resilience of interdependent socio-ecological systems requires improved understanding of multi-level processes and coordination efforts to be focussed on reducing these mismatches (Cumming et al. 2006). This implies that decisions on policy for sustainable development, including mitigation strategies and capacity for adaptation to climate change, that are built and coordinated over multiple levels of governance will increase the potential of arriving at coherent and acceptable local, regional and global management strategies. Secondly, multi-level decision-making processes are also considered to be a growing necessity, as resources required for control over decision-making and action implementation are increasingly distributed between actors with different sectorial interests, who have responsibilities for decisions at different administrative levels of governance. This means that it is increasingly rare that any one government department, private company or interest group has sufficient power and resources to implement its policy decisions without the help of other groups (Daniell 2008). However, how such processes 
of multi-level, multi-stakeholder coordination and decision-aiding can be effectively and efficiently designed, put in place and improved over time is still a major challenge in need of investigation (Berkes 2002; Dietz et al. 2003; Hooghe 2003; Adger et al. 2005b; Cumming et al. 2006; Olsson et al. 2007; Nykvist 2008; Reidsma et al. 2009; Daniell et al. 2010a). Finally, as with the majority of environmental management issues, designing processes to aid multi-level policy development for managing climate change and its impacts, as part of the sustainability challenge, is fraught with a large number of practical and political complexities. As well as the first two reasons, this includes the sectorial challenges of climate policy development, as shown in Figure 2.

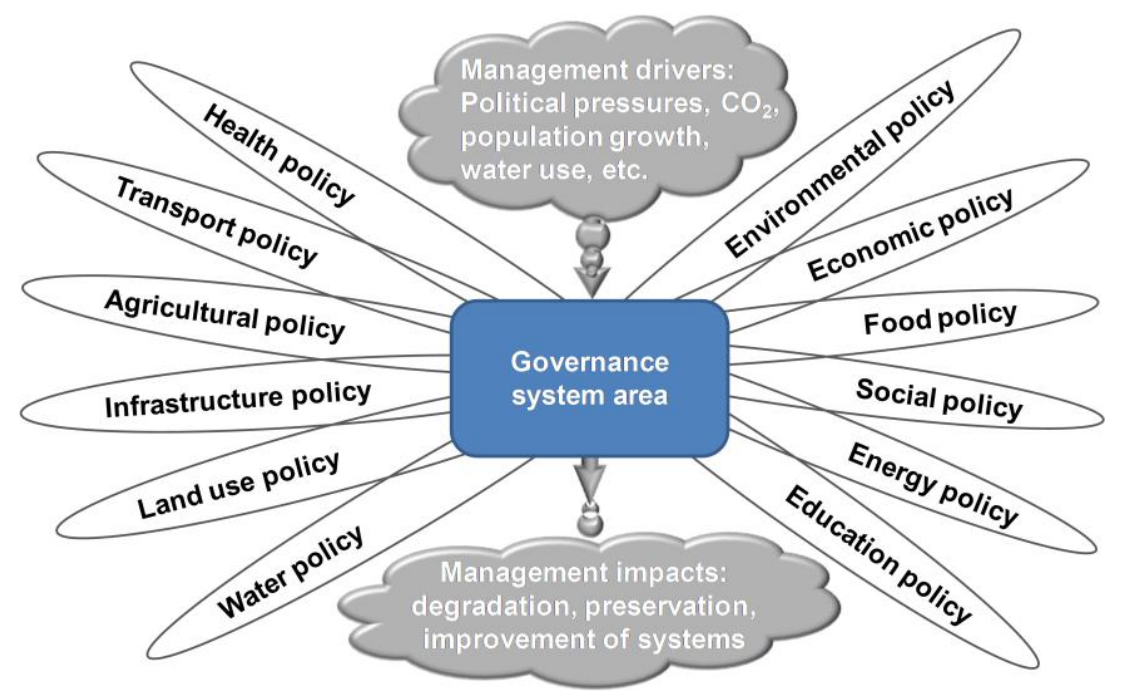

Figure 2 Conceptualisation of the multi-sectorial governance challenge of climate change mitigation and adaptation. Due to the nature of climate policy, interaction with other policies at each territorial or administrative level is unavoidable as climate change and its theoretical governance-system area are likely to impact and be affected by almost all sectors of society and the policies developed for them.

The call for increasing "climate policy integration", which can be defined as: "the incorporation of the aims of climate change adaptation and mitigation into all stages of policy-making in other policy sectors (nonenvironmental as well as environmental); complemented by an attempt to aggregate expected consequences for climate change adaptation and mitigation into an overall evaluation of policy, and a commitment to minimise contradictions between climate policies and other policies" (Mickwitz et al. 2009, p.19) stems in large part from analyses of this sectorial challenge. Nevertheless, it is important to note that some scepticism remains around the perceived advantages of "policy integration" approaches that seek coherence and coordination of policies across sectors and multiple levels of administration. Specifically, processes that promote policy integration and coherence are seen to threaten traditional multi-level governance systems, where "constitutional, legal and political obstacles to policy co-ordination exist partly in order to maintain clear distribution of responsibilities and specialisation of tasks between sectors and across the various levels of government" (OECD 2002). Some authors are also pointing out apparent failures and the lack of headway that has been made in implementing "Environmental Policy Integration" around the world (Jordan and Lenschow 2008), the movement that is seen as Climate Policy Integration's predecessor. Some barriers are linked to the conceptual confusion surrounding the term, Environmental Policy Integration (EPI), such as whether it refers to what occurs in the policy process, the substantive policy output, or both (Persson 2004), and hence whether these two integrations have been successfully achieved. Likewise, defining measures of the "success" of the integration is problematic as some authors consider EPI in a normative fashion (see Lafferty and Hovden (2003) who state environmental 
Author-produced version of the article published in Regional Environmental Change, 2010, 11(2), 243-258.

The original publication is available at http://link.springer.com

DOI : $10.1007 / \mathrm{s} 10113-010-0162-0$

objectives should be given "principled priority" over all others), while some look at EPI challenges in an organisational or procedural light (Underdal 1980; United Nations 1992; OECD 2002). Some failures from the normative point of view are seen when there is a general lack of commitment or political will to strongly push the need for environmentally sustainable policies and practices over other interests (Jordan and Lenschow 2008), which are often driven by short-term vs. long-term factors in decision-making (Dovers and Hezri 2010). Other authors go further in their analyses to determine to what extent certain types of integration are desirable, or even possible (Liberatore 1997; Peters 1998; OECD 2002; Persson 2004; Rosenau 2005). For example, the writings of Rosenau on the concept of "fragmegration" or the clashes between the contradictory forces of "globalisation, centralisation and integration on the one hand" and "localisation, decentralisation, and fragmentation on the other" (Rosenau 2005), show that possibilities for integration are only ever partial and will always have side effects of fragmenting other parts of the multi-level and multi-sectorial systems being integrated. In light of this discussion, we therefore consider that finding a workable balance of what needs to be integrated and what can be broken into parts to work towards climate change aware regional sustainable development is one of the key challenges to be tackled when aiding decision-making processes.

\section{Overcoming the challenges of aiding multi-level decision-making process}

To deal with these complexities, the contested natures of policy development and the challenges of coordinating decision-making throughout multi-level systems, many authors advocate the need for different interactive forms of governance that: (1) are able to cross multiple scales and sectorial or territorial divisions (Bache and Flinders 2005; Cash et al. 2006); and (2) promote the creation of workable relations and sharing of decision-making authority between the policy, science and public spheres (Dryzek 1990; Forester 1993; Funtowicz and Ravetz 1993; Callon et al. 2001; OECD 2002; Fischer 2003). In recent years, significant progress has been made in coordinating and aiding decision-making related to a limited number of individual actions at certain governance levels by using a range of participatory methods to foster exchange and cooperation in groups or network structures. For example, at the local level there are many success stories of participatory methods used with community environmental groups, water catchment committees and farmers' associations to coordinate action and build collective capacity and resilience to change (Pretty 2003). International and regional networks of scientists, politicians, managers, interest groups and NGOs are likewise continuing to attempt to develop knowledge systems for sustainability, and to coordinate information dissemination and policy-making processes. These groups or networks are commonly aided by internet technologies and large, organized forums for discussion. The potential benefits of "boundary organisations", "co-management", and "institutional interplay" for such aims and for dealing with cross or multi-level environmental issues are also documented (Cash et al. 2003; Adger et al. 2005a; Cash et al. 2006), but examples linked to climate change adaptation and mitigation are rare. Progress on bringing larger groups of community representatives, government officials and other stakeholders together to jointly investigate environmental policy problems in a strongly interactive and participatory manner has also seen rapid expansion. Even though it is now ten years old, Holmes and Scoones (2000) present an indepth analysis of 35 such participatory processes in the environmental policy domain and identify a number of key issues that require additional investigation, including: who convenes these processes and how the convenors influence the processes and their translation into policy decisions and practical implementation; how discussions on values, ethics and politics can influence the framing of these processes; and how the transparency and verifiability of the processes can be assured. From their analyses related to these issues, Holmes and Scoones (2000) found that the majority of the processes were convened by individual, often local, 
Author-produced version of the article published in Regional Environmental Change, 2010, 11(2), 243-258.

The original publication is available at http://link.springer.com

DOI : $10.1007 / \mathrm{s} 10113-010-0162-0$

government agencies that they critiqued in some cases for bending the processes to meet their own agendas. Even in cases where external NGOs, private sector groups or international donors were the key organisers, the power of these groups over key decisions and framing of the processes were noted, in particular over the choice of methods used that could silence policy assessment and discussions based on values, ethics and politics in the guise of a strong focus on implementation. Finally, the lack of audit trails sufficient to ensure the transparency and verifiability of what had occurred in these processes and their impacts was seen to be a major gap, in all but one of the cases they studied. This is a particularly problematic issue, as without in-depth audit or evaluation programs to monitor decision-making processes, it is difficult to understand how decisions were arrived at and to what extent they meet the aims of supporting coherent and acceptable management strategies. In-depth more recent investigations of such issues are still surprisingly rare (although work in evaluation of participatory processes is accelerating - see Rowe and Frewer (2004) and Jones et al. (2009) as examples), and so our research intends to strengthen and highlight work that is aimed at filling these gaps and providing alternative examples. In particular, we find it surprising that Holmes and Scoones found few cases where researchers were convening and driving the decision-aiding processes, and are interested in what differences could occur if it was the case. The challenges of successfully bridging the multiple levels of stakeholders participating in the processes were also not brought to the fore and are in need of greater investigation.

In light of these gaps and remaining research challenges, this paper aims to investigate and discuss the viability of possible research-supported methods of aiding multi-level decision-making processes for integrating climate change mitigation and adaptation strategies into regional sustainable development agendas. Our additions to the current discussions in the literature will be based on examples from four regional case studies: the Lower Hawkesbury River region in Australia; the Upper Iskar Basin in Bulgaria; the Comunidad Valenciana autonomous region of Spain; and the Faridpur District of Bangladesh. These particular cases have been chosen for a number of reasons, including that they: included multiple administrative levels and sectorial interests at each level, that were interested in developing regionally coherent and acceptable multi-level policies and responses; at least one of the co-authors was personally involved in the experimental design, implementation and analysis of the cases; and each of the cases was extensively evaluated (formatively and ex-post), providing audit trails that could be examined by the other co-authors. Brought together, these cases allow the examination of research-supported approaches to aiding multi-level decision-making in a diversity of different political, environmental and cultural governance systems, which provides a rich base for identifying a range of barriers to, and possibilities for, using such approaches to work towards climate change aware regional sustainable development.

\section{RESEARCH METHODS}

Before describing and discussing insights from the multi-level cases, we will first outline the underlying research methods used to support their design and investigation: participatory intervention and experimental participatory research.

\section{Participatory intervention research}

The research method of participatory intervention is one where a number of researchers intervene in a situation with "purposeful action to create change" (Midgley 2000). More specifically, we consider that for this type of research, pre-established theories or models are explicitly used and re-examined through interventions in 
management processes to create new forms of collective action and "actionable knowledge" (Hatchuel and Molet 1986; Avenier et al. 1999; David 2000). Participatory intervention research is therefore a collaborative effort, with the "purposeful design" and adaption of the research process collectively negotiated, often between researchers, government officials, NGOs and stakeholders. We will return to this key issue in the discussion linked to our cases. Evaluation procedures are also an integral part of participatory intervention research. They perform the key role of providing feedback on the design and implementation of a multi-level participatory process with a range of decision-makers and affected stakeholders. A diagram of a participatory intervention research process, as it was proposed for use in the Australian and Bulgarian cases, is presented in Figure 3.

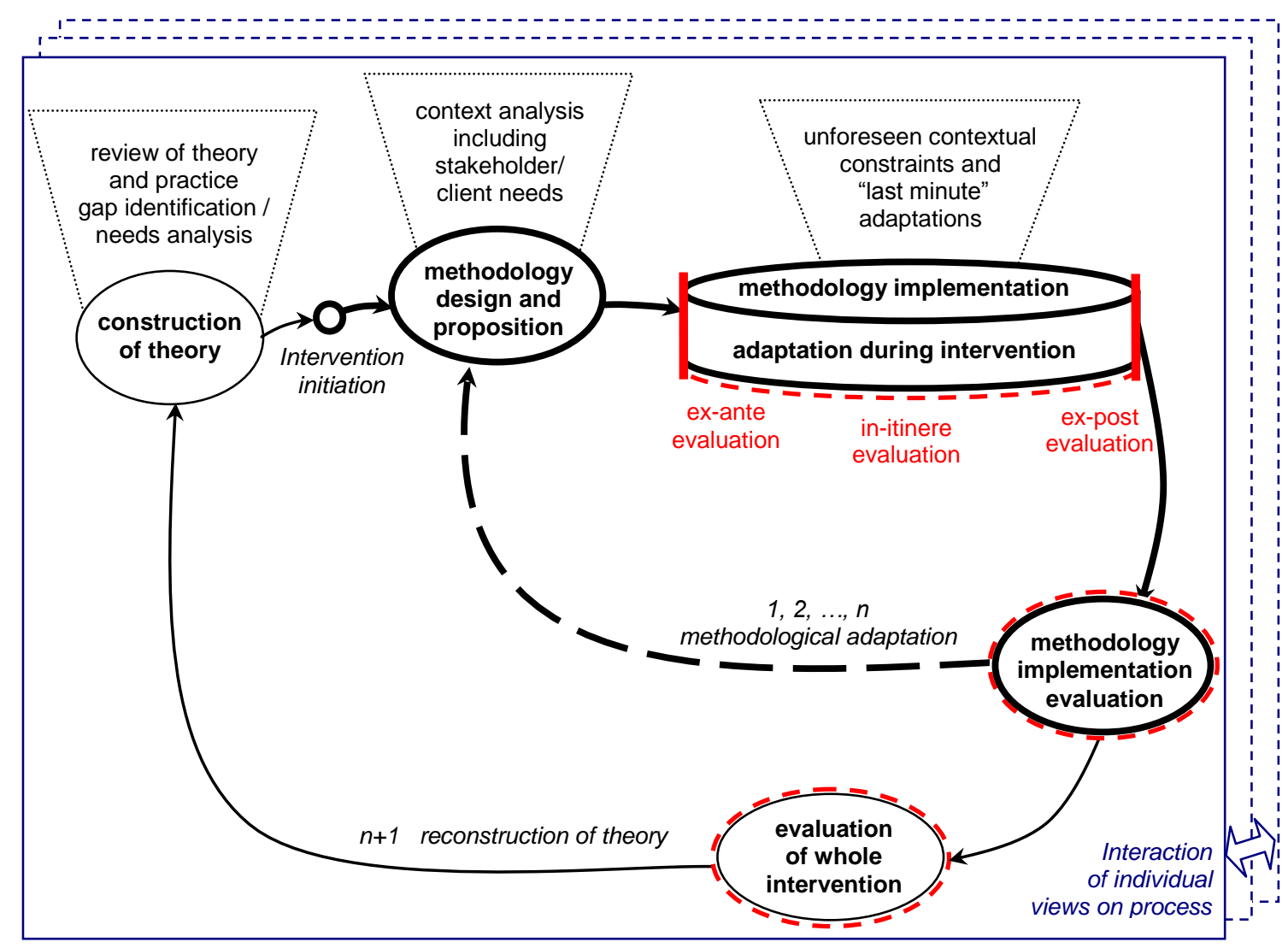

Figure 3 Participatory intervention research process description (Daniell 2008)

Implementation of this research method in the cases took the form of a series of facilitated workshops with separated and combined groups of actors from different territorial levels (State, regional or local). The small "methodological adaptation" loop represents the process carried out for each workshop, of which there were 3 in the Australian case and 15 in the Bulgarian case. The large loop represents the understanding that comes from one whole case intervention before another is pursued. Only the ex-ante evaluation of each workshop in our cases was not completed due to a lack of time and collective decisions of the project teams against it.

The Bangladeshi case was a hybrid of this approach and the well-known Participatory Rural Appraisal (PRA) method (Chambers 1994; Cornwall 1996), with the details being negotiated between external researchers and local NGO workers. The PRA workshops were carried out with the local level stakeholders and interviews were 
Author-produced version of the article published in Regional Environmental Change, 2010, 11(2), 243-258.

The original publication is available at http://link.springer.com

DOI : $10.1007 / \mathrm{s} 10113-010-0162-0$

carried out with the representatives of greater territorial levels. Further information on the cases will be provided in the next section.

\section{Experimental participatory research}

The other research method represented through our cases is one of "experimental" participatory research, where a specific testing protocol that has the aim of enhancing multi-level stakeholder participation in policy design is pre-designed by researchers. The specific form of experimental design investigated here is a "two-level policy experiment" that is designed to facilitate an in-situ policy design feedback loop, as shown in Figure 4.
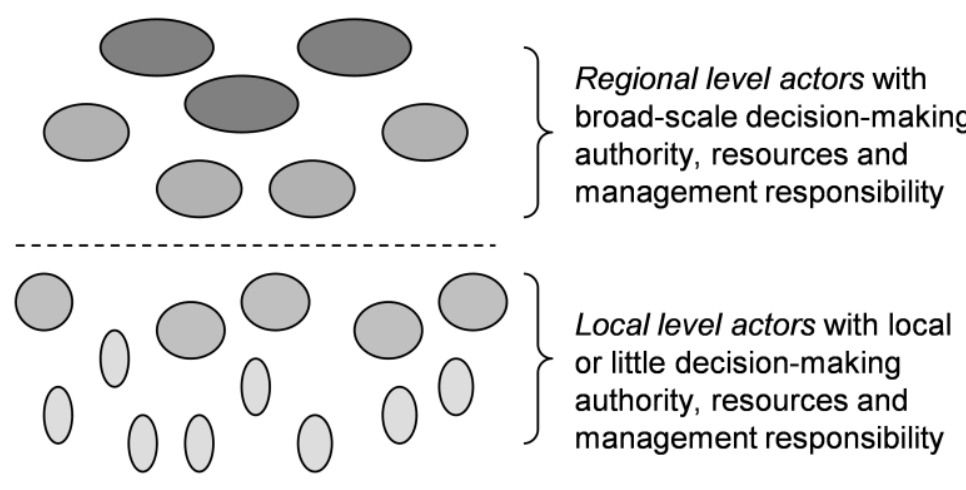

Local level actors with local or little decision-making authority, resources and management responsibility
Policy design stage

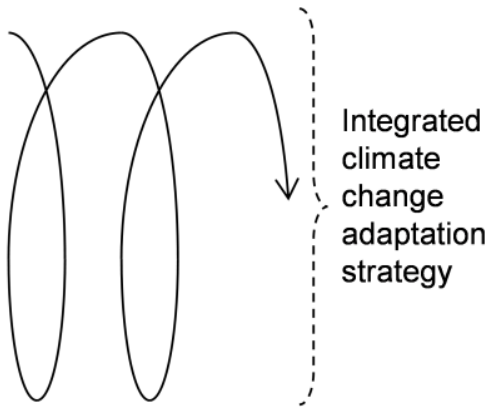

Policy response stage

Figure 4 Configuration of "Two-level policy experiments" for climate change adaptation and mitigation

The approach incorporates policy design, policy impact scenarios and responses to policy. It is therefore an alternative or complementary approach to the more classical "top-down" policy analysis (Jaeger et al. 1998; Beierle and Konisky 2000; Blomquist et al. 2005; Gordon 2008; Llop 2008; Gokhale 2009) based on the policy description, as it also includes "bottom-up" components in an iterative process. The specifics of the implementation of this experimental approach for the Spanish case are shown in Figure 5.

\section{Phase Content}

1. Collecting insights on current policies and possible strategies for improving policy coherence

2. Collecting information for determining policy impacts on the decision-making processes and behaviours of local level actors.

3. Workshop for designing climate scenarios, an integrated climate change policy and implementation strategy

4. Role playing game workshop to test social responses to the climate policy (simulating a 10-20 year period)

5. Vertical confrontation workshop with both groups to discuss cross-level policy coherency and responses

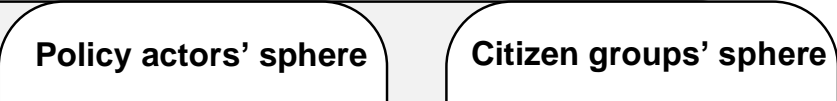

Policy analysis interviews at national and regional level

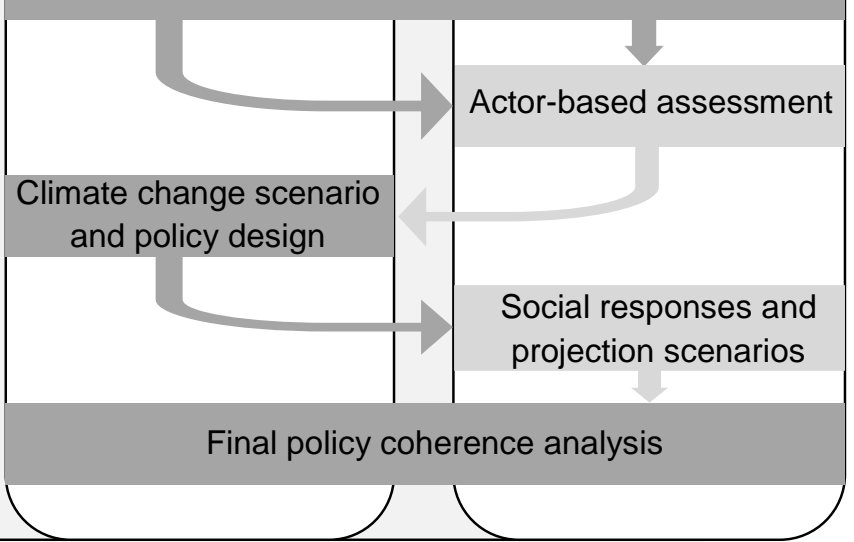

Figure 5: Spanish climate policy integration experiment (Máñez et al. 2009) 
Author-produced version of the article published in Regional Environmental Change, 2010, 11(2), 243-258.

The original publication is available at http://link.springer.com

DOI : $10.1007 / \mathrm{s} 10113-010-0162-0$

We now move on to examine the cases where these research methods were used to aid multi-level decisionmaking for climate change aware regional sustainable development.

\section{MULTI-LEVEL REGIONALLY-FOCUSSED CASE STUDIES}

Each of the case studies presented in this paper have been designed, implemented and evaluated by researchers who were driven to develop multi-level processes for specific reasons. The key objectives and drivers of the multi-level approaches used to aid regionally focused decision-making are outlined here, supplemented by a comparative table providing an overview of the organizational, procedural and substantive characteristics of each case. These aspects will then be drawn upon for the following section that discusses a range of identified barriers to, and possibilities for, using such approaches to work towards climate change aware regional sustainable development. All of the focus regions share a number of similar environmental characteristics despite their diverse socio-political contexts. The most important for our analyses are that climate change impacts are already perceived to be changing regional climatic patterns and, along with high regional population growth, are accentuating problems of water stress (like flood, drought and pollution) that put livelihoods, regional industries and community well-being at risk.

\section{Estuarine risk management in the Lower Hawkesbury, Australia}

The Australian case, investigated through participatory intervention research, was developed with the objective of creating a new regionally coherent "Lower Hawkesbury Estuary Management Plan". This environmentally sensitive peri-urban region on the northern fringe of Australia's largest city, Sydney, has experience in developing participatory processes that are inclusive of stakeholders for aiding decision-making about issues of sustainable development for the area. The political and social culture has long since addressed the inadequacy of using public meetings for public consultation (refer to Holmes and Scoones 2000) by having many community stakeholder management bodies currently actively involved in aiding local decision-making in collaboration with local Government authorities. However, the current fragmentation of estuary management guided by plans developed by adjacent local governments and stakeholder committees (that covered only $50 \%$ of the region's common estuary) and lack of coordination of management actions from these areas and higher levels of Government, were considered to be inadequate for the sustainable management of the estuary (Kimmerikong 2005). The driver for the multi-level approach to aiding estuarine management decision-making was therefore to concurrently upscale the local participatory stakeholder management to the regional level and provide a forum for downscaling multiple pieces of New South Wales State legislation and policies from other levels into a set of coherent regional management strategies and actions to treat estuarine risks. The process used for the regional plan creation, which is now legislated through both local governments in the region and is being implemented, is summarised in Table 1.

\section{Flood and drought risk management in the Upper Iskar Basin, Bulgaria}

The Bulgarian case, also investigated via participatory intervention research as part of the European Commission financed "AquaStress" project, took place in the Upper Iskar Basin and was developed with the objective of building the region's capacity to cope with flood and drought risks. The Upper Iskar Basin encompasses the nation's fast growing capital, Sofia, which has suffered severe impacts of both extreme floods and droughts in recent years, that some consider to be a function of inadequate or corrupt water, land and infrastructure management at a range of levels and not just due to climatic extremes or climate change (Staddon 1999; Knight et al. 2004; Ellison 2007). Having a tumultuous transition to democracy through the 1990s following 
Author-produced version of the article published in Regional Environmental Change, 2010, 11(2), 243-258.

The original publication is available at http://link.springer.com

DOI : $10.1007 / \mathrm{s} 10113-010-0162-0$

the fall of the Eastern Bloc, Bulgaria is now in its second phase of socio-political transition, as the country has ascended to being a part of the European Union (EU). Participatory management processes, especially led internally by Bulgarian government agencies, are uncommon and capacity building at all levels of community and government is seen as a necessity for the country if is to meet its obligations to the EU and ensure the sustainable development of its regions under this new governance configuration. In this context, the process developed for Upper Iskar Basin was driven by the need to empower communities to take part in managing the flood and drought risks to their own lives and livelihoods, as well as to improve coordination and collaboration between multiple sectors and levels of the region's technocratic management structures. The process, implemented as outlined in Table 1, included interviews and workshops with individual governance levels (National policy makers, regional mayors and stakeholders, and local citizens), as well as "vertically integrated" workshops for multi-level exchange and collaborative planning.

\section{Climate policy integration in the Comunidad Valenciana, Spain}

The Spanish case was carried out as part of the European PEER network on climate change and with the objective of implementing a "two-level policy experiment" to encourage multi-level analysis and exchange for climate policy integration in the Comunidad Valenciana. This autonomous region on the eastern coast of Spain is considered to have already recorded decreases in rainfall since the 1980s due to climate change, and temperatures are expected to steadily rise over the coming decades, exacerbating water scarcities, desertification and soil erosion (Máñez et al. 2009; IPCC 2007). Having already suffered climate disruptions in the past, Spain and its autonomous regions have a strong history in adaptation and in developing contingency plans, in particular to cope with recurrent drought (Máñez et al. 2009). Participatory approaches to deal with environmental conflicts are becoming common (for a recent water conflict example see Andreu et al. 2009), but more rarely used for land planning and management, which is considered a key activity for the mitigation of, and adaptation to, climate change (Máñez et al. 2009). Climate policy, including national mitigation strategies and adaption plans, has been largely developed from the "top-down", first by the National Government and then by the Autonomous Regions' Governments. Failure to understand the preferences and responses of the general public and other interest groups like property developers to these policies is considered to be one of the reasons for Spain being on track to seriously overshoot their Kyoto targets, as are the differences in priorities between the National and Regional Governments (Máñez et al. 2009). Understanding the social responses to policy and making them part of the climate policy development process was the key driver of the experiment. Further aspects of the case are provided in Table 1.

\section{Food security in the Faridpur District, Bangladesh}

The Bangladeshi case, implemented as a participatory research intervention, had the objective of better understanding the food system security under climate change in Faridpur District. Faridpur is located in central Bangladesh, west south west of Dhaka, at the confluence of the River Ganges and Meghna. The district contains regions exposed to moderate annual flooding and areas exposed to severe flooding. Bangladesh is considered to be one of the countries the most vulnerable to climate variability and change, due to its low-lying topography and climatic conditions, widespread poverty, malnutrition rates, high population density and limited institutional capacity. The country has relatively high civil liberties and levels of civic engagement, but with its fragile democracy, common political instability and rampant corruption, the central government and other administrative institutions are lacking in effectiveness and accountability (Freedom House 2007). Due to the weak government, aid donors and NGOs commonly run participatory processes throughout Bangladesh 
Author-produced version of the article published in Regional Environmental Change, 2010, 11(2), 243-258.

The original publication is available at http://link.springer.com

DOI : 10.1007/s10113-010-0162-0

autonomously, without engaging with government structures (Freedom House 2007). Although these processes have had much success for helping the rural poor and marginalised to find livelihoods to support them that can maintain their dignity, without engaging with higher levels of government who have greater control over some drivers of food security and disaster management such as access to markets and development of infrastructure, it is difficult to understand how the vulnerability and adaptive capacity of districts' food systems under climate change conditions will be affected. The driver of this multi-level investigative research process (method previously outlined and process documented in Table 1) was therefore to better understand the collection and interactions of environmental factors, governance mechanisms and local actions contributing to food system vulnerability. In this process, officials from multiple levels of government were engaged, as well as local people.

A summary comparative overview of the cases is shown in Table 1.

Table 1 Multi-level case descriptions

\begin{tabular}{|c|c|c|c|c|}
\hline & Australia & Bulgaria & Spain & Bangladesh \\
\hline $\begin{array}{l}\text { Process } \\
\text { objective }\end{array}$ & $\begin{array}{l}\text { Create a regional estuary } \\
\text { management plan }\end{array}$ & $\begin{array}{l}\text { Test a multi-level participatory } \\
\text { modelling process for joint flood } \\
\text { and drought risk management }\end{array}$ & $\begin{array}{l}\text { Test a social experiment for } \\
\text { the design of policy } \\
\text { instruments: climate policies }\end{array}$ & $\begin{array}{l}\text { To better understand } \\
\text { climate change adaptation } \\
\text { planning for food systems }\end{array}$ \\
\hline $\begin{array}{l}\text { Key driver of } \\
\text { multi-level } \\
\text { approach }\end{array}$ & $\begin{array}{l}\text { Upscaling estuary } \\
\text { management beyond local } \\
\text { government boundaries } \\
\text { and downscaling state } \\
\text { legislation into regional } \\
\text { actions }\end{array}$ & $\begin{array}{l}\text { Institutional and local capacity } \\
\text { building and cross-level social } \\
\text { learning }\end{array}$ & $\begin{array}{l}\text { Policy development process } \\
\text { that explicitly incorporates } \\
\text { social response feedback }\end{array}$ & $\begin{array}{l}\text { Understanding } \\
\text { environmental factors, } \\
\text { governance mechanisms } \\
\text { and local actions } \\
\text { contributing to food system } \\
\text { vulnerability }\end{array}$ \\
\hline $\begin{array}{l}\text { Participating } \\
\text { stakeholders/ } \\
\text { levels of } \\
\text { involvement }\end{array}$ & $\begin{array}{l}\text { State Government } \\
\text { Departmental } \\
\text { representatives; Local } \\
\text { Government Councillors; } \\
\text { managers, planners and } \\
\text { scientists; national } \\
\text { environmental NGO; } \\
\text { Catchment Management } \\
\text { Authority representative; } \\
\text { regional associations, } \\
\text { industries and commerce; } \\
\text { regional water agency } \\
\text { managers; local residents. }\end{array}$ & $\begin{array}{l}\text { National Ministers and } \\
\text { Departmental representatives; } \\
\text { National NGOs, association } \\
\text { representatives and water } \\
\text { experts; Water Basin } \\
\text { Directorate representatives; } \\
\text { regional mayors; regional water } \\
\text { agency manager; municipal } \\
\text { representatives; local residents. }\end{array}$ & $\begin{array}{l}\text { Autonomous Government } \\
\text { and Regional } \\
\text { representatives; National and } \\
\text { regional NGOs; River basin } \\
\text { authorities' technical } \\
\text { directors; regional mayors; } \\
\text { opposition politicians; } \\
\text { environmental journalists; } \\
\text { technical advisors for } \\
\text { agriculture, water, nature, } \\
\text { tourism and urban planning; } \\
\text { energy sector } \\
\text { representatives, housewives' } \\
\text { association; fishermen and } \\
\text { farmers. }\end{array}$ & $\begin{array}{l}\text { National Government } \\
\text { (ministry and technical } \\
\text { agencies); District (Zila) } \\
\text { Government; Local } \\
\text { (Upazila) Government; } \\
\text { Union Government; } \\
\text { international, national and } \\
\text { local NGOs; small } \\
\text { business; small and } \\
\text { marginal rural farmers. }\end{array}$ \\
\hline $\begin{array}{l}\text { Process } \\
\text { organisation }\end{array}$ & $\begin{array}{l}\text { Research-supported: } \\
\text { government funded. } \\
\text { Project team of Local } \\
\text { government water } \\
\text { managers, university } \\
\text { researchers, private } \\
\text { environmental engineering } \\
\text { consultants } \\
\end{array}$ & $\begin{array}{l}\text { Research-driven: EU funded } \\
\text { (FP6). Project team of } \\
\text { university researchers, } \\
\text { government institute } \\
\text { researchers, private research } \\
\text { consultants, stakeholder group }\end{array}$ & $\begin{array}{l}\text { Research-driven: European } \\
\text { research project funded by } \\
\text { PEER. Project team of } \\
\text { researchers. }\end{array}$ & $\begin{array}{l}\text { Research-driven: } \\
\text { university funded. Project } \\
\text { team of a university } \\
\text { researcher, national and } \\
\text { district NGOs and } \\
\text { stakeholder group. }\end{array}$ \\
\hline $\begin{array}{l}\text { Participatory } \\
\text { process } \\
\text { outline }\end{array}$ & $\begin{array}{l}3 \text { workshops with } 38 \\
\text { participants (average of } 22 \\
\text { per workshop) }\end{array}$ & $\begin{array}{l}2 \text { sets of interviews and } 15 \\
\text { workshops with approximately } \\
135 \text { participants (First } 10 \\
\text { workshops: average } 8 \text {; Last two } \\
\text { workshops: average 26) }\end{array}$ & $\begin{array}{l}2 \text { sets of interviews: local and } \\
\text { autonomous level. } 2 \\
\text { workshops and } 1 \text { inception } \\
\text { session (average of } 15 \\
\text { participants per workshop) }\end{array}$ & $\begin{array}{l}3 \text { focus groups ( } 20 \\
\text { participants in each) and } \\
30 \text { semi-structured } \\
\text { interviews }\end{array}$ \\
\hline $\begin{array}{l}\text { Length of } \\
\text { process }\end{array}$ & $\begin{array}{l}\text { 2006-2009, workshops } \\
\text { carried out over } 4 \text { months }\end{array}$ & $\begin{array}{l}2006-2008, \text { workshops carried } \\
\text { out over one year }\end{array}$ & $\begin{array}{l}\text { 2008, process carried out } \\
\text { over } 6 \text { months }\end{array}$ & $\begin{array}{l}2009 \text {, focus groups and } \\
\text { interviews carried out over } \\
2 \text { months }\end{array}$ \\
\hline $\begin{array}{l}\text { Evaluation } \\
\text { programme }\end{array}$ & $\begin{array}{l}\text { Questionnaire at the end of } \\
\text { each workshop for } \\
\text { participants, observation of } \\
\text { workshops by an } \\
\text { anthropologist and video- } \\
\text { recorded, interviewing of } \\
\text { process organisers through } \\
\text { the process }\end{array}$ & $\begin{array}{l}\text { Questionnaire at the end of } \\
\text { each workshop for participants, } \\
\text { some observation and video- } \\
\text { recording of workshops, } \\
\text { interviewing and debriefing of } \\
\text { process organisers through the } \\
\text { process }\end{array}$ & $\begin{array}{l}\text { Questionnaire at the end of } \\
\text { each workshop for } \\
\text { participants, video-recording } \\
\text { of workshops, and debriefing }\end{array}$ & $\begin{array}{l}\text { Feedback session after } \\
\text { each focus group, } \\
\text { observation and audio } \\
\text { recording of focus groups, } \\
\text { ongoing interviews }\end{array}$ \\
\hline
\end{tabular}


Author-produced version of the article published in Regional Environmental Change, 2010, 11(2), 243-258.

The original publication is available at http://link.springer.com

DOI : $10.1007 / \mathrm{s} 10113-010-0162-0$

\begin{tabular}{|c|c|c|c|c|}
\hline $\begin{array}{l}\text { Key } \\
\text { procedural } \\
\text { insights }\end{array}$ & $\begin{array}{l}\text { Strongly negotiated } \\
\text { process and evaluation } \\
\text { design; safe space for } \\
\text { inter-sectorial management } \\
\text { group dialogue created by } \\
\text { separating levels for one } \\
\text { workshop; process led to } \\
\text { planning institutionalisation } \\
\text { at a new regional scale }\end{array}$ & $\begin{array}{l}\text { Strongly negotiated process } \\
\text { design; separating levels for a } \\
\text { series of workshops then } \\
\text { vertically integrating them was } \\
\text { conducive to high levels of } \\
\text { learning and effective multi- } \\
\text { level dialogue; language barrier } \\
\text { aided local facilitator training } \\
\text { and process appropriation }\end{array}$ & $\begin{array}{l}\text { High level of control over } \\
\text { design by researchers; } \\
\text { imposed design aided inter- } \\
\text { sectorial dialogue and } \\
\text { awareness of social } \\
\text { responses; lack of } \\
\text { stakeholder buy-in to process }\end{array}$ & $\begin{array}{l}\text { Shared control of focus } \\
\text { group design between } \\
\text { local NGO and } \\
\text { researchers; on-the- } \\
\text { ground constraints and } \\
\text { language barrier impacted } \\
\text { researcher's capacity to } \\
\text { negotiate process design }\end{array}$ \\
\hline $\begin{array}{l}\text { Key } \\
\text { substantive } \\
\text { insights }\end{array}$ & $\begin{array}{l}\text { Perceived criticality of } \\
\text { climate change (calculated } \\
\text { as greatest risk to estuary } \\
\text { against } 15 \text { others); } \\
\text { proactive management to } \\
\text { provide set-back areas for } \\
\text { ecosystems to migrate } \\
\text { landwards with sea level } \\
\text { rise and to develop } \\
\text { adaptive planning } \\
\text { mechanisms to adhere to } \\
\text { larger territorial climate } \\
\text { adaptation strategies }\end{array}$ & $\begin{array}{l}\text { Stakeholders affected by floods } \\
\text { perceived climate change as } \\
\text { more critical than scientists or } \\
\text { policy makers (who find issues } \\
\text { of finance, pollution and lack of } \\
\text { management capacity more } \\
\text { important); after dialogue a } \\
\text { suite of both technical and non- } \\
\text { technical options to manage } \\
\text { flood and drought risks were } \\
\text { proposed including education } \\
\text { programs, insurance and } \\
\text { hydrotechnic infrastructure }\end{array}$ & $\begin{array}{l}\text { National level policy makers } \\
\text { more concerned about } \\
\text { mitigation and meeting Kyoto } \\
\text { targets while local level } \\
\text { concerned about the effects } \\
\text { land-use regimes on climatic } \\
\text { conditions (which } \\
\text { corresponds to scientific } \\
\text { evidence - see Millán 2007) } \\
\text { and water scarcity; mismatch } \\
\text { between perceptions and } \\
\text { priorities of levels problematic } \\
\text { for developing coherent } \\
\text { policies and responses }\end{array}$ & $\begin{array}{l}\text { Food security coping } \\
\text { strategies vary significantly } \\
\text { between disaster and non- } \\
\text { disaster periods (i.e. } \\
\text { floods); current lack of } \\
\text { communication and } \\
\text { understanding between } \\
\text { levels, especially bottom- } \\
\text { up; many vulnerabilities of } \\
\text { food system could be } \\
\text { reduced with greater } \\
\text { capacity building at all } \\
\text { levels to improve both } \\
\text { governance and local } \\
\text { action capacities }\end{array}$ \\
\hline References & $\begin{array}{l}\text { Daniell 2008, BMT WBM } \\
\text { 2008, Daniell et al. 2010a }\end{array}$ & $\begin{array}{l}\text { Daniell 2008, Ribarova, } 2008 \\
\text { Daniell et al. 2010a, Ribarova } \\
\text { et al. } 2010\end{array}$ & Máñez et al. (2009) & Kingsborough (2009) \\
\hline
\end{tabular}

\section{DISCUSSION}

We now turn to analysing a number of key methodological and procedural insights emanating from these multilevel regionally-focused cases, comparing and contrasting them with the established literature. We start with reflections on the research-supported nature of the procedural aids used, in particular exploring the place of informal policy development processes or "experiments" for overcoming the barriers of existing multi-level governance systems. We then move on to examining organisational challenges associated with implementing such processes, including how it is typically not one key convenor who has power over the process and what this means for developing new multi-level policy development experiments. This is followed by an investigation of the progress made towards the ideals of climate policy integration and coherence in our cases and what general conclusions can be drawn from them. We then end with a section of speculative insights and propositions aimed to promote future research and work towards climate change aware regional sustainable development, before our conclusions summarise the key innovations this paper presents.

\section{Overcoming barriers to policy integration through informal research-supported multi-level processes}

Aiding decision-making for climate change aware sustainable development in multi-level governance contexts is inherently political, whether or not it is supported by researchers. Inertia in the governance landscape and scepticism of the advantages of new multi-level processes that threaten the status quo of existing governance mechanisms and power structures, which have often been created with a range of checks and balances to enhance accountability (OECD 2002), are typical barriers that prevent processes of policy integration from being effectively implemented. Many traditional participatory environmental policy processes promote the need for citizens to have more power over the choices for their own lives, and this is sometimes seen as threatening for government authorities who develop policies but remain largely divorced from local level implementation of actions related to the policies (refer to Figure 1). However, when understanding exists not only in communities but also in multiple levels of government structures, that to be able to function effectively and promote sustainable regional development they need to work together or at least understand each others' views and 
Author-produced version of the article published in Regional Environmental Change, 2010, 11(2), 243-258.

The original publication is available at http://link.springer.com

DOI : $10.1007 / \mathrm{s} 10113-010-0162-0$

behaviours, the door is opened to considering proposals for how this challenge may be overcome. In such an atmosphere, researchers promoting the use of multi-level processes in the form of informal experiments for aiding decision-making at a range of levels appear to be a non-threatening mechanism to start this work, as they are not linked to formal legislated procedures and the decision-makers are not obligated to follow the suggested policy recommendations (see also Olsson et al. 2006 and Mollenkamp et al. 2010 on advantages of informal processes). Further willingness and comfort in participating in multi-level processes also seem to be able to be attained when individual levels such as National policy makers, regional managers and local citizens are provided with separate spaces to investigate their own views and issues, rather than all being lumped together from the start in one room, as is fairly common practice in previously documented multi-level participatory environmental policy processes (Holmes and Scoones 2000). This insight was backed up from the evaluations of all of our cases, where separate arenas for discussion or interviews were used for different purposes. In the Australian case, giving the policy makers and managers a space to discuss the estuarine risks independently from the community members in one workshop was found to enhance more open communication than when community members were also present, due to managers not having to present the "public" views of their organisations and fear confrontation with community members, as was typically common in joint meetings. In the Bulgarian case, and similarly in the Spanish case but with only two levels, each group of actors from different levels involved in the process had the opportunity to independently work through their identification and assessment of the risks, as well as the development of management strategies to deal with them, before coming together to discuss their common understanding and mutual interdependence. This procedural choice not only helped people feel comfortable with their own views and opinions, but also built their capacity to use participatory methods to more effectively communicate with one another before bringing the levels together, which appeared vital to the success of such a process in a strongly technocratic management regime where participants had little experience in participatory approaches (Daniell 2008). In the Bangladeshi case, separately running workshops for the local people and then individual interviews with Government officials at a range of levels aided openness of all participants to identify their individual priorities and barriers they experience at their own respective levels. However, time and resource constraints of the research project and Bangladeshi NGO prevented the development of face-to-face multi-level exchange, to work on the capacity building across all levels, which was identified as vital by the researchers' analyses to reduce the District's food system vulnerability in the face of climate change. How multi-level participant interactions would work in the Bangladeshi political landscape will require further investigation. On top of the relative informality of the research-supported processes, often the possibility of receiving external financing for experimental policy processes also helps to build interest for participation in them. If the processes fail to gain support for continuation by the participants there is little loss to their behalf unless hope for the process is too strongly built up (see Barreteau et al. 2010 for further discussion on this point) and there is also the possibility that a successful process can lead to a formalisation of new governance mechanisms, as occurred in the Australian case. It is worth noting that the level of research support is likely to influence this institutionalisation or formalisation, as the Lower Hawkesbury planning process, despite being strongly supported by research for the participatory process design and evaluation, was also driven and funded by one local government, and implemented in conjunction with private consultants (see Table 1). Therefore, finding what balance of research and management interests, and from which levels, is required for convening multi-level participatory processes that are more likely to lead to long term change is still a key question in need of further investigation. These issues of process organisation will be further discussed in the next section. 
Author-produced version of the article published in Regional Environmental Change, 2010, 11(2), 243-258.

The original publication is available at http://link.springer.com

DOI : 10.1007/s10113-010-0162-0

\section{Hidden challenges of multi-level process organisation}

Multi-level processes used to aid the creation of new policies and implementation plans for sustainable development rarely occur without some form of organisation group promoting that specific interactions take place. As was the case for our processes, these groups or networks may even be inter-organisational or potentially multi-level processes in their own right (see Table 1). In our cases, researchers were involved in each of these organisation groups. They commonly had to negotiate their visions and needs for the design, implementation and evaluation of the multi-level processes with government officials, private consultants, NGOs and stakeholders who also took part in varying roles in the process organisation groups. Although research is starting into the analysis of the negotiations that take place in the organisation groups of such multi-level processes (e.g. through "co-engineering" practice in Daniell et al. 2010a), or how successful collaborations can be built for mutual benefit (e.g. the "trialogue team" examined in Moellenkamp et al. 2010), the general impacts of these complex and participatory organisation processes on bringing about on-the ground change, and changing the scientific and political landscapes, have been less well investigated. What we want to highlight in this paper is that the researchers who are involved in promoting and organising these multi-level processes are clearly enmeshed in political processes. The researchers effectively become stakeholders in the processes they are organising and their beliefs and relations to other organisers and participants in the process have the potential to have real policy and on-the-ground impacts (see also Meijerink and Huitema 2010). In multi-level processes, one of the key issues facing researchers is how to get a range of stakeholders, often including very busy high level officials, to be willing to give up their time to participate in unknown and potentially uncomfortable processes. For higher levels to participate it seems important to have respected champions who are in, or closely support, the organisation team, so that they have some confidence that their interests will be looked after. This respect or confidence in the organisers and their supporters may stem from either personal trust and existing relationships or be an issue of reputation, such as is often the case for external funders, aid organizations and academics from well known institutions. Reputation often seems adequate to encourage people to participate at the start of a process, but if they soon fail to see what is in it for them, it may be insufficient to maintain participation or for them to finally take the experience to heart and work to implement the recommendations on completion of the research-supported exercise. This reputation of researchers and their institutions was important in both the Bangladesh and Spanish cases, where high-level ministry officials agreed to participate in the exercises, but there was not enough interest built up over the short research projects for follow-ups to occur. In Bangladesh, the trust required to help ensure local people participated in the research was developed by partnering with a local NGO who already worked in the region. This was positive as it meant that follow-ups at the local level could be supported without the researchers, but also created challenges for them as, due to on-the-ground constraints, they were unable to negotiate that the NGO help them to organise broader multi-level participatory process. The Australian case functioned differently, as a well respected and trusted local government official played a key role in both bringing the researchers (to drive innovation) and consultants (to carry out the scientific and legislative reviews and manage the planning project) into the organising team, and in getting all government officials, stakeholders and community members in to participate. Reputation of the success on the workshops then drove continued participation and the building of links between the stakeholders that were sufficient for collective decisions to be made to support the plan and its implementation. In Bulgaria, good personal networks of one of the organising team members into the ministries, the possibility of EU funds, and the personal trust developed between the majority of participants and the Bulgarian organizers and facilitators, was the key to the success of the multi-level process including some of the 
Author-produced version of the article published in Regional Environmental Change, 2010, 11(2), 243-258.

The original publication is available at http://link.springer.com

DOI : $10.1007 / \mathrm{s} 10113-010-0162-0$

stakeholders appropriating the experience and being able to influence the organisation team into altering the process focus in a way that would lay a better path for follow-up initiatives (see Daniell et al. 2010a for details). Partnering with respected and well connected locals or organizations to aid the design and implementation of the research is therefore the key for researchers, if more than just a one-off experiment is hoped for. Understanding the importance of working with local champions is well known in the development literature (e.g. Hanna and Picciotto 2002; IDS 2007). Nevertheless, however beneficial it may be to work with one or a number of local champions at different levels (close to national ministries, local governments and community stakeholders), it may also lead to difficult negotiations over the shared responsibilities, directions, and roles to be taken in the organisation of the process. As the organisation team grows beyond just one agency, these negotiations and their evaluation (as were carried out through the evaluation protocols used in our cases - see Table 1) can help to create the checks and balances required to prevent one agency bending the process easily to suit their own personal agenda (as was considered a problem in Holmes and Scoones' (2000) review). How such participatory organisation processes and other political factors may or may not drive progress towards climate policy integration and coherence in sustainable regional development is investigated in the next section.

\section{Investigating progress towards climate policy integration and coherence}

Due to the complexity of developing policies and actions to promote climate change aware regional sustainable development, it is inevitable that multiple boundary judgements (Midgley 2000) must be made or negotiated over what is included and excluded from policies and who is responsible and accountable for their implementation. Such decision-making on boundaries may occur formally, for example in Australia the decision of the Prime Minister to name the Government's ministries and division of responsibilities across them, or between levels of government as laid out in a country's constitution and other legislation. It may also occur informally as decisions are influenced and negotiated, for example in the organisation teams over who is to participate in aiding decision-making processes and what focal issues are chosen for the process. This is important, as focal issues are typically integrated into new policy frameworks, whereas other issues may be excluded or fragmented away from the new "integrated policies". How climate issues may either be formed into policies on their own or be integrated into existing policy areas is therefore a key decision. In our own cases, we have two examples where a bottom-up approach to climate mainstreaming into existing policy areas was taken (estuary management in the Lower Hawkesbury, Australia, and food security in the Faridpur District of Bangladesh). The other two cases took more direct approaches: in the Comunidad Valenciana of Spain to aid the development of an integrated climate policy; and in the Upper Iskar Basin of Bulgaria to develop strategies for better coping with climate extremes. In the Bulgarian process other key sectors' interests (e.g. education, finance, land use planning and water management for multiple uses) had to be brought back into the strategies for treating flood and drought risks. This was similar to the Spanish case, except that different levels of actors had clearly different priorities over what should be included or excluded, such as that local stakeholders wanted land use planning to be considered an integral part of climate change mitigation and adaptation policies, unlike the National level stakeholders. In both cases the mismatches between priorities (either climate priorities between governance levels in the Spanish case or sectorial priorities that compete with climate-related priorities in the Bulgarian case) will likely impact the move towards greater climate policy integration in these regions in the near future. In the Australian and Bangladesh cases, multi-level analyses of the estuarine and food systems rather internally uncovered and led to the assessment of the relative importance of climate risk impacts for the sustainability of the systems and the need to manage them accordingly. In the Australian case especially, the analysis and final 
Author-produced version of the article published in Regional Environmental Change, 2010, 11(2), 243-258.

The original publication is available at http://link.springer.com

DOI : $10.1007 / \mathrm{s} 10113-010-0162-0$

plan covered a very broad range of sectors and had hundreds of detailed management actions (BMT WBM 2008). Yet what were excluded were the other adjoining local government areas, upstream and downstream of the focal estuarine area. As this process has now been seen to have made good management progress (HSC 2009), it could be suggested that these other adjoining areas of the landscape could similarly be fragmented into regional size portions of two or more local government areas, with the fragments being coordinated by a higher level body such as a Catchment or Basin Management Authority that would work on aiding coherence building between plans. How coherence of individual actions could be developed to reach overall desirable socioenvironmental states still needs greater investigation. This is an exceedingly difficult challenge given the many uncertainties, including human behaviours and environmental processes, but some headway is being made by researchers in the complex systems science domain (e.g. Perez and Batten 2007; Edmonds and Moss 2010). What has a greater chance of more easily being made coherent is where resources will be used and who is made responsible and accountable for individual actions under the overarching policies (for a start on this work see Daniell et al. 2010b).

\section{Speculation and future areas of research}

The multi-level cases highlighted and analysed in this paper present only a couple of types of research-based approaches for promoting climate change aware regional sustainable development. Much other work is being pursued both within and outside public administrations on how to more effectively deal with the pervasiveness of the climate change challenge. With climate change a growing political concern, many countries are developing formal institutions and a range of other mechanisms to cater for the priority (Mickwitz et al. 2009). For example, Australia and Spain have recently created new national ministerial departments specifically dedicated to climate change, and inserted "climate change" into the names of departments at other administrative levels; changes which appear to be serving the role of keeping the climate change issue politically active and financially supporting a large number of climate change related programmes. How effective this integration of environmental and economic priorities has been is a key subject in need of future investigation. Bangladesh has a Climate Change Cell, which was originally established as part of a UNDP-led project and is now a unit within the Department of Environment. However, it is now recognised that the Cell currently lacks sufficient institutional capacity to achieve its goals, and needs to sit outside the Department of Environment if it is to be more effective in affecting policies and actions across all ministries. The Cell has so far worked by training a Climate Change "focal point" in each Ministry, but there have been ongoing problems in terms of ensuring the effectiveness of this strategy (Kingsborough 2009). In Bulgaria climate change does not yet appear to be high enough on the country's political agenda to have key institutions developed for it, perhaps due to the raft of other key challenges facing this new EU Country in the short-term, such as improving management of the economy, finances, organised crime and corruption (CIA 2010).

Considering the diversity of current approaches to setting up and maintaining institutions, including stemming from research-supported processes as our Australian case showed, one potentially beneficial area of future research would be to further investigate the historical creation processes and effects of the new climate change institutions at a variety of interwoven levels, to determine to what extent they are achieving their stated aims of creating greater climate policy coherence and effectively mitigating climate change effects and adapting to them. Some good studies of this type have recently been published (e.g. Monni and Raes 2008), yet expanding such analyses to also tackle other issues linked to climate change, such as population and ecosystem migration and 
Author-produced version of the article published in Regional Environmental Change, 2010, 11(2), 243-258.

The original publication is available at http://link.springer.com

DOI : $10.1007 / \mathrm{s} 10113-010-0162-0$

dealing with increased climate variability, including food security and health impacts of extreme weather, would likely prove fruitful. Further study is also required to confirm the procedural insights from our research-supported multi-level regionally-focussed cases, and in particular, to determine whether useful protocols for the co-design of multi-level decision-aiding processes can be developed, which allow for the need of specific contextualisation of participatory methods to different social-political and environmental systems, and identification of key people required in organising teams. Whether the researchers embrace this reality in their research method, admitting that the processes are collectively negotiated with others for needs and values including their own, or avoid such negotiations, is likely to have impacts on the appropriation of the multi-level processes and their outcomes by the other participants as we have previously discussed. We therefore see that future work in determining what kinds of organisation group make-up work well for promoting effective multi-level processes in different countries and regions should be a priority. This is likely to be possible through a joint method of studying existing political theory and theories on inter-organisational management, as well as many more carefully evaluated trial processes around the world, like the ones presented in this paper. As well as this, tracking and exploring how public perceptions of climate change, their associated institutions and policy instruments, and making decisions about mitigation and adaption measures, develop over time in different regions, could prove beneficial for other regions just beginning to see climate change as an issue and wondering how to start to address it.

One final speculative thought driven by the Australian and Bulgarian case studies relates to whether it could be useful to develop risk-based multi-level governance models, where management actions could be linked to triggers. For example, if a monitored environmental variable exceeds a commonly agreed threshold (decided by multiple levels of governments, scientists and other stakeholders), then certain action plans could be put into place at the appropriate levels. Such an approach, which could be adapted based on new knowledge (i.e. changing triggers by $+/-10 \%$ on new information), might also help to overcome the impasses of set "binary" policies, such as land use zonings where certain types of developments are either allowed or not allowed. To illustrate the importance of a different type of approach, we could consider coastal property development. Using the current binary model, the land zoning map would demonstrate what types of developments are permissible or not. If a notification is added to the map to show that it will be flooded due to climate change scenarios, then the land will effectively be sterilized and considered not fit for use. However, if the scientific estimates were found to be different in a few years, and that in fact the land did not need to be completely prohibited from development, then this land could again be put up for use. We speculate that risk-based multi-level governance approaches could promote more adaptive practices that may better account for the inherent uncertainties embedded in climate change science and its associated predictions. Many governments and businesses at a range of levels currently support risk-based approaches to management, but how effectively it could also be used for policy development and whether other stakeholders would accept it (due to emerging criticism of some risk-based approaches - see Rothstein et al. 2006 and Hom et al. 2009) are well worthy of further study and practical testing.

\section{CONCLUSION}

Research-supported multi-level processes can be developed and implemented to aid decision-making for regional climate change aware sustainable development in a variety of socio-political environments. The comparative informality of research-supported processes not developed under formal legislation can provide arenas for policy makers, managers and stakeholders at a range of territorial governance levels to both understand their own views 
Author-produced version of the article published in Regional Environmental Change, 2010, 11(2), 243-258.

The original publication is available at http://link.springer.com

DOI : $10.1007 / \mathrm{s} 10113-010-0162-0$

and behaviours (such as policy propositions and social responses), as well as those of others in a relatively nonthreatening environment. Dividing levels into separate arenas for some parts of the participatory process appears conducive to providing a non-threatening environment for exchange and mutual learning, rather than having all stakeholders together at all times. Depending on the partnering relationships of the researchers with local champions or organisations who are influential in the region, potential exists for the initially informal processes to lead to the institutionalisation of new processes and structures with climate-related policy objectives and actions built in, as was seen in our Australian case study where the new upscaled regional estuary management plan is now legislated by the involved local governments and in the process of being implemented. Organisation processes that involve multiple parties, as seems typical for multi-level participatory processes, is fraught with challenges often due to the organisers' conflicting objectives for the process, but their negotiation and resolution can provide a forum for checks and balances to occur that help to ensure one agency or person is able to drive the policy process too much to suit their own interests. Process evaluation that can provide audit trails of both the interorganisational design and the multi-level stakeholder processes is also possible and can be an aid for ensuring the transparency of the processes and a mechanism for stakeholders to use to be able to influence the multi-level process in tangible ways. The influence of a group of Bulgarian stakeholders on the organization of the end of our Bulgarian case's process is one such example that has been carefully tracked and transparently reported on. Research-supported experiments for aiding decision-making for climate change mitigation and adaptation in regions can also be developed with different aims in key policy areas such as food systems or estuarine systems. For example, climate-related issues were mainstreamed naturally into the analyses as key drivers and impacts that became an integrated part of the plans and analyses in the Bangladeshi and Australian cases. More direct approaches bringing policy makers and citizens together in a structured way to address climate-policy integration from a "climate policy" angle, which included bringing other sectors interests in under a concern of climate variability and change, were taken in the Spanish and Bulgarian cases where the experiments were developed in an attempt to project the participants into possible future social contexts under climate scenarios. This allowed participants to collectively prepare proposals for new climate policy configurations including with significant flood and drought risks, and to start to consider some current issues in the configurations of their policies and priorities, even if concrete actions are yet to emanate from either process. To propel this preliminary understanding developed from these research-supported cases further, much future research and evaluations of case study examples of multi-level processes and how they are organised can be envisaged, in order to continue work towards climate change aware regional sustainable development around the world.

\section{Acknowledgements}

Thank you to all the participants in the four multi-level processes for their time, work efforts and enthusiasm, and to our colleagues at BMT WBM, SJB Planning, Hornsby Shire Council, The Australian National University, UACEG, Cemagref, Seecom Deutschland GmBH, SodaSed, Oxford University, Centre for Global Change, Racine and the PEER network for their support, work and management in the projects. The Bulgarian part of this work was financially supported by the European Commission, 6th Framework program, AquaStress project, contract GOCE Contract No. 511231-2. The contents of this presentation are the sole responsibility of the authors and can under no circumstances be regarded as reflecting the position of the European Union. Grateful acknowledgement is given to the other financial supporters of this research including the General Sir John Monash Foundation, Cemagref, CSIRO and the Fenner School of Environment and Society at the Australian National University. We also thank two anonymous reviewers whose insightful suggestions have led to an improved paper. 
Author-produced version of the article published in Regional Environmental Change, 2010, 11(2), 243-258.

The original publication is available at http://link.springer.com

DOI : 10.1007/s10113-010-0162-0

\section{REFERENCES}

Adger WN, Brown K, Tompkins EL (2005a) The political economy of cross-scale networks in resource comanagement. Ecol \& Soc 10(2): 9

Adger WN, Hughes TP, Folke C, Carpenter SR, Rockström J (2005b) Social-Ecological Resilience to Coastal Disasters. Sci 309: 1036. DOI: 10.1126/science.1112122

Ahmed IH (2009) Climate Policy Integration: Towards Operationalization, March 2009, DESA Working Paper No. 73, United Nations, New York

Andreu J, Pérez MA, Paredes J, Solera A (2009) Participatory analysis of the Jucar-Vinalopo (Spain) water conflict using a Decision Support System. Proceedings of the 18th World IMACS / MODSIM Congress, 13-17 July 2009, Cairns, Australia: 3230-3236

Avenier M-J, Nourry L, Sweeney M (1999) Sciences of the Artificial and Knowledge Production: The Crucial Role of Intervention Research in Management Sciences. Des Issues 15: 55-70

Bache I, Flinders M (2005) Multi-Level Governance, Oxford University Press, Oxford.

Barreteau O, Bots PWG, Daniell KA (2010) A framework for clarifying "participation" in participatory research to prevent its rejection for the wrong reasons. Ecol \& Soc 15(2): 1

Beierle TC, Konisky DM (2000) Values, conflict, and trust in participatory environmental planning. J Policy Analysis and Manag 19: 587-602

Berkes F (2002) Cross-scale institutional linkages: perspectives from the bottom up. In: Ostrom E, Dietz T, Dolsak N, Stern P, Stonich S, Weber EU (Eds), The drama of the commons, National Academy Press, Washington, D.C.

Blomquist W, Tonderski A, Dinar A (2005) Institutional and Policy Analysis of River Basin Management - The Warta River Basin, Poland, World Bank Policy Research Working Paper, Number 3528

BMT WBM (2008) Lower Hawkesbury Estuary Management Plan. R.N1252.003.03. BMT WBM. Prepared for the Hornsby Shire Council, NSW, Australia

Callon M, Lascoumes P, Barthe Y (2001) Agir dans un monde incertain: Essai sur la démocratie technique. Seuil, Paris

Cash DW, Clark WC, Alcock F, Dickson NM, Eckley N, Guston DH, Jäger J, Mitchell RB (2003) Knowledge systems for sustainable development. PNAS 100: 8086-8091

Cash DW, Adger W, Berkes F, Garden P, Lebel L, Olsson P, Pritchard L, Young O (2006) Scale and cross-scale dynamics: governance and information in a multilevel world. Ecol \& Soc 11(2): 8

Chambers R (1994) Participatory Rural Appraisal (PRA): Analysis of Experience, World Dev 22:1253-1268

CIA (2010) The World Factbook: Bulgaria, Central Intelligence Agency, US Government. https://www.cia.gov/library/publications/the-world-factbook/geos/bu.html. Accessed 25 July 2010

Cornwall A (1996) Towards participatory practice: participatory rural appraisal (PRA) and the participatory process. In: de Koning K, Marion M (Eds), Participatory Research in Health: Issues and Experiences, Zen Books Ltd, London

Cumming GS, Cumming DHM, Redman CL (2006) Scale mismatches in social-ecological systems: causes, consequences, and solutions. Ecol \& Soc 11(1): 14

Daniell KA (2008) Co-engineering participatory modelling processes for water planning and management (2 Volumes), PhD Thesis, Australian National University, Canberra and AgroParisTech, Montpellier

Daniell KA, Ferrand N, White I, Coad P, Ribarova IS, Rougier J-E, Hare M, Popova A, Jones N, Burn S, Perez P (2010a) Co-engineering participatory water management processes: insights from Australia and Bulgaria, Ecol \& Soc (IN PRESS)

Daniell KA, Mazri C, Tsoukiàs A (2010b) Real world decision-aiding: a case of participatory water management. In: Rios Insua D, French S (Eds) e-Democracy: A Group Decision and Negotiation Perspective, Springer (IN PRESS)

David A (2000) La recherche-intervention, cadre général pour la recherche en sciences de gestion ? In: David A, Hatchuel A, Laufer R (Eds), Les nouvelles fondations des sciences en gestion, Vuibert, collection FNEGE, Paris

Dietz T, Ostrom E, Stern PC (2003) The Struggle to Govern the Commons. Sci 302: 1907-1912. DOI: $10.1126 /$ science. 1091015

Dovers (2005) Environment and sustainability policy: creation, implementation and evaluation. The Federation Press, Sydney.

Dovers SR, Hezri AA (2010) Institutions and policy processes: the means to the ends of adaptation Wiley Interdisciplinary Reviews: Climate Change 1(2): 212-231

Dryzek JS (1990) Discursive democracy: politics, policy and political science. Cambridge University Press, New York.

Edmonds B and Moss S (2010) Simulating Social Complexity: A Handbook. Springer (IN PRESS). 
Author-produced version of the article published in Regional Environmental Change, 2010, 11(2), 243-258.

The original publication is available at http://link.springer.com

DOI : $10.1007 / \mathrm{s} 10113-010-0162-0$

Ellison BA (2007) Public Administration Reform in Eastern Europe: A Research Note and a Look at Bulgaria, Administration \& Soc, 39: 221-232

Fischer F (2003) Reframing Public Policy: Discursive Politics and Deliberative Practices. Oxford University Press, Oxford

Folke C, Pritchard L, Berkes F, Colding J, Svedin U (2007) The problem of fit between ecosystems and institutions: ten years later. Ecol \& Soc 12(1):30

Forester J (1993) Critical Theory, Public Policy, and Planning Practice: Towards a Critical Pragmatism. State University of New York, Albany

Freedom House (2007) Country Report - Bangladesh: Countries at the Crossroads 2007, Freedom House Inc, Washington D.C. http://www.freedomhouse.org/uploads/ccr/country-7132-8.pdf

Funtowicz SO, Ravetz JR (1993) Science for the post-normal age. Futures 25: 739-755

Gokhale J (2009) Financial Crisis and Public Policy. Policy Analysis 634: 1-24

Gordon RI (2008) The case against government intervention in energy markets. Revisited once again. Policy Analysis 628: 1-32

Hanna N, Picciotto R (2002) Making development work: development learning in a world of poverty and wealth, Transaction Publishers, New Brunswick, NJ

Hatchuel A, Molet H (1986) Rational modelling in understanding and aiding human decision-making: about two case studies. Eur J Oper Res 24: 178-186

Hom AG, Plaza RM, Feijóo SF, Palmén R (2009) From precautionary inadequacy to participatory risk management. Futures, 41(5):260-268. DOI:10.1016/j.futures.2008.11.006

Hooghe L, Marks G (2003) Unraveling the central state, but how? Types of multi-level governance. Political Science Series, Institute for Advanced Studies, Vienna.

HSC (2009) Estuary Management Program 2008-2009 Annual Report, Water Catchments Team, Hornsby Shire Council, Hornsby, Australia.

IDS (2007) Champions of Participation: Engaging Citizens in Local Governance. International Learning Event Report, 31 May-4 June 2007, Brighton, UK. http://www2.ids.ac.uk/logolink/resources/downloads/Champions\%20Report.pdf

IPCC (2007) Climate Change 2007, the IPCC Fourth Assessment Report (4 Volumes), Intergovernmental Panel on Climate Change, Cambridge University Press, Cambridge.

Jaeger CC, Renn O, Rosa EA, Webler T (1998) Decision analysis and rational action. In: Rayner S and Malone E (Eds), Human Choice and Climate Change: The tools for policy analysis, Battelle Press, Washington D.C.

Jones N, Perez P, D’Aquino P, Measham TG, Kelly G, Daniell KA, Dray A, Ferrand N (2009) Evaluating Participatory Modeling: developing a framework for cross-case analysis. Environmental Management, 44 (6): 1180-1195

Jordan AJ, Lenschow A (2008) Innovation in Environmental Policy? Integrating the Environment for Sustainability, Edward Elgar, Cheltenham, UK

Kimmerikong (2005) Hawkesbury-Nepean River Estuary Management - Scoping Study - Final Report, Kimmerikong Pty Ltd Natural Resource Management, NSW, Australia

Kingsborough, AB (2009) Cross-level Governance and Adaptive Capacity in Food Systems: A case study of Faridpur District, Bangladesh. Masters Thesis, University of Oxford, Oxford

Knight CG, Raev I, Staneva MP (2004) Drought in Bulgaria: A Contemporary Analog for Climate Change, Ashgate, Aldershot, UK

Lafferty W, Hovden E. (2003) Environmental policy integration: towards an analytical framework. Environ Polit 12:1-22

Liberatore A (1997) The Integration of Sustainable Development Objectives into EU Policy Making: Barriers and Prospects. In: Baker S, Kousis M Richardson D, Young S (Eds) The politics of sustainable development: theory, policy and practice within the European Union, Routledge, London

Llop M (2008) Economic impact of alternative water policy scenarios in the Spanish production system: an inputoutput analysis. Ecol Econ 68: 288-294. DOI: 10.1016/j.ecolecon.2008.03.002

Máñez M, Aix F, Ferrand N (2009) Spanish Country Report on Climate Change Adaptation and Mitigation Strategies. Actors' based assessment. PEER Project, Cemagref, Montpellier, France

Marks G, Hooghe L (2004) Contrasting visions of multi-level governance. In: Ian B and Flinders M (Eds), Multilevel governance, Oxford University Press, Oxford

Meijerink S, Huitema D (2010) Policy entrepreneurs and change strategies: lessons from sixteen case studies of water transitions around the globe. Ecol \& Soc 15(2): 21

Mickwitz P, Aix F, Beck S, Carrs D, Ferrand N, Görg C, Jennsen A, Kivimaa P, Kuhlike C, Kuindersma W, Máñez M, Melannen M, Monni S, Pedersen AB, Reinert H, Van Bommel S (2009) Climate Policy 
Author-produced version of the article published in Regional Environmental Change, 2010, 11(2), 243-258.

The original publication is available at http://link.springer.com

DOI : 10.1007/s10113-010-0162-0

Integration, Coherence and Governance. PEER report, Partnership for European Environmental Research, Helsinki

Midgley G (2000) Systemic intervention: philosophy, methodology, and practice. Kluwer Academic / Plenum Publishers, New York

Millán M (2007) Europa, el cambio climático y las políticas de energía y transportes. El País, Valencia

Moellenkamp S, Lamers M, Huesmann C, Rotter S, Pahl-Wostl C, Speil K, Pohl W(2010) Informal Participatory Platforms for Adaptive Management. Insights into Niche-finding, Collaborative Design and Outcomes from a Participatory Process in the Rhine Basin. Ecol \& Soc (IN PRESS)

Monni S, Raes F (2008) Multilevel climate policy: the case of the European Union, Finland and Helsinki. Environ Sci \& Policy 11: 743-755. DOI:10.1016/j.envsci.2008.08.001

Nykvist B (2008) EPI in Multi-level Governance - A literature review, EPIGOV Paper, Institute for International and European Environmental Policy, Berlin

OECD (2002) Improving policy coherence and integration for sustainable development: a checklist. OECD, Paris

Olsson P, Folke C, Galaz V, Hahn T, Schultz L (2007) Enhancing the fit through adaptive co-management: creating and maintaining bridging functions for matching scales in the Kristianstads Vattenrike Biosphere Reserve Sweden. Ecol \& Soc 12: 28

Olsson P, Gunderson LH, Carpenter SR, Ryan P, Lebel L, Folke C, Holling CS (2006). Shooting the rapids: navigating transitions to adaptive governance of social-ecological systems. Ecol \& Soc 11: 18

Peters BG (1998) Managing horizontal government: the politics of coordination. Research Paper No. 21, January 1998, Canadian Centre for Management Development, Ottawa

Perez P and Batten D (2007), Complex Science for a Complex World, ANU E Press, Canberra, Australia.

Persson A (2004) Environmental Policy Integration: An Introduction, Policy Integration for Sustainability Background Paper, June 2004, Stockholm Environment Institute, Stockholm

Pretty J (2003) Social Capital and the Collective Management of Resources. Sci 302: 1912-1914. DOI: 10.1126/science.1090847

Reidsma P, Ewert F, Lansink AO, Leemans R (2009) Vulnerability and adaptation of European farmers: a multilevel analysis of yield and income responses to climate variability. Reg Environ Chang, 9: 25-40. DOI: 10.1007/s10113-008-0059-3

Ribarova I., Assimacopoulos D, Jeffrey P, Daniell KA, Inman D, Vamvakeridou-Lyroudia LS, Melin T, Kalinkov P, Ferrand N, Tarnaki K (2010) Research-supported participatory planning for water stress mitigation, J of Environ Plan \& Manag (IN PRESS)

Ribarova I, Ninov PI, Daniell KA, Ferrand N and Hare M (2008) Integration of technical and non-technical approaches for flood identification, Proceedings of the Water Down Under 2008 International Conference, Adelaide, Australia

Rothstein H, Irving P, Walden T, Yearsley R (2006) The risks of risk-based regulation: Insights from the environmental policy domain. Environment International, 32(8):1056-1065.

DOI:10.1016/j.envint.2006.06.008

Rosenau JN (2005) Strong demand, huge supply: governance in an emerging epoch. In: Bache I and Flinders M (Eds) Multi-Level Governance, Oxford University Press, Oxford, UK

Rowe G and Frewer LJ (2004) Evaluating Public Participation Exercises: A Research Agenda. Sci Technology \& Hum Values, 29 (4): 512-556. DOI: 10.1177/0162243903259197

Staddon C (1999) The Changing Meaning of Place in Post-Socialist Eastern Europe: Commodification, Perception and Environment Localities, Natural Resources and Transition in Eastern Europe. The Geogr J, 165: 200-208

Underdal A (1980) Integrated marine policy: What? Why? How? Marine Policy, 4(3):159-169

United Nations (1992) Agenda 21, United Nations Conference on Environment and Development, United Nations, New York 